BULLETIN OF PNRPU. GEOLOGY. OIL \& GAS ENGINEERING \& MINING

ВЕСТНИК ПНИІУ. ГЕОЛОГИЯ. НЕФТЕГАЗОВОЕ И ГОРНОЕ ДЕЛО

ISSN 2224-9923

Volume/Tom 15 №20 2016

http://vestnik.pstu.ru/geo/

УДК 550.38

Article / Статья

(C) PNRPU / ПНИПУ, 2016

\title{
THE LITHOLOGICAL-PETROGRAPHY CHARACTERISTICS OF CHALK, PALEOGEN-MIOCENE DEPOSITS OF YALAMA-KHUDAT AREAS AND SIYAZAN MONOCLINE ANTICLINE IN CONNECTION WITH THEIR OIL AND GAS CONTENT (SOUTH-EAST IMMERSIONS OF MEGAANTICLINORIC OF GREATER CAUCASUS)
}

\author{
V.Sh. Gurbanov, N.R. Narimanov, L.A. Sultanov, G.G. Abbasova, M.S. Ibragimli
}

Azerbaijan State Oil and Industry University (20 Azadlyg av., Baku, AZ1010, Republic of Azerbaijan)

\section{ЛИТОЛОГО-ПЕТРОФИЗИЧЕСКИЕ ХАРАКТЕРИСТИКИ МЕЛОВЫХ, ПАЛЕОГЕН-МИОЦЕНОВЫХ ОТЛОЖЕНИЙ ПЛОЩАДЕЙ ЯЛАМА, ХУДАТ И СИЯЗАНСКОЙ МОНОКЛИНАЛИ В СВЯЗИ С ИХ НЕФТЕГАЗОНОСНОСТЬЮ (ЮГО-ВОСТОЧНОЕ ПОГРУЖЕНИЕ МЕГАНТИКЛИНОРИЯ БОЛЬШОГО КАВКАЗА)}

\section{В.Ш. Гурбанов, Н.Р. Нариманов, Л.А. Султанов, Г.Г. Аббасова, М.С. Ибрагимли}

Азербайджанский государственный университет нефти и промышленности (AZ1010, Азербайджанская Республика, г. Баку, пр. Азадлыг, 20)

Received / Получена: 4.03.2016. Аccepted / Принята: 10.08.2016. Published / Опубликована: 30.09.2016

Key words:

petrophysics, density, porosity,

mesokaynozoic, oil and gas

accumulation rocks,

lithofacies, graphical analytic

method, collector, analytic

content, the velocity of

longitudinal waves, terrigenous-

carbonate formations, trough,

drilling, geophysics, reef. \begin{abstract}
In recent years, geological prospecting and geophysical works in Azerbaijan were carried out in considerable volume in
order to study an oil and gas potential of Meso-Cenozoic deposits. Based on the results of these studies the criteria were order to study an oil and gas potential of

It is known that the sedimentation basin mainly dipped in the Meso-Cenozoic time. As a result, the researchers have no It is known that the sedimentation basin mainly dipped in the Meso-Cenozoic time. As a result, the researchers have no
doubt about the potential of these deposits in the central part of the studied area and at greater depths, but there have been doubt about the potential of these deposits in the central part of the studied area and at greater depths, but there have been
no precise calculations yet. In order to solve this problem, we have studied the reservoir rocks properties of considered ages no precise calculations yet. In order to solve this problem, we have studied the reservoir rocks properties of considered ages
of Khudat, Yalama oil and gas bearing structures and Siyazan monocline formed in Gusar-Davachi superimposed mulde in of Khudat, Yalama oil and gas bearing structures and Siyazan monocline formed in Gusar-Davachi superimposed mulde in various geological conditions and at different depths. For an easier analysis, all the actual data are given in tables showing the physical parameters of the different rock types, involved in geological structure of oil and gas bearing areas. In order to
clarify the obtained results and the changes nature study of the considered physical properties the various petrophysical clarify the obtained results and the changes nature study of the considered physical properties the various petrophysical
methods were applied. As a result the regularity in changing of rocks density, carbonate contents, porosity, permeability methods were applied. As a result the regularity in changing of rocks de

and the propagation velocity of ultrasonic waves in them were established. However, in tectonically complex structures of the Siyazan monocline the applied methods have not given expected results of studies because of their severe dislocation and outlet to the surface. Taking this into account the reservoir characteristics studies of rock samples of considered ages from fields being developed in the north-eastern slop Caucasus dipping were conducted.

The main objective is to study the petrophysical parameters and reservoir rocks properties of the Cretaceous, PaleogeneMiocene age in tectonically complex uplifts of Yalama, Khudat and Siyazan monocline placed at southeast Greater Caucasus dipping due to its petroleum potential.
\end{abstract}

В последние годы в Азербайджане в значительном объеме проводились геолого-поисковые и геофизические работы с целью изучения перспектив нефтегазоносности мезокайнозойских отложений. На основании результатов этих работ выработаны критерии, которые являются основой для проведения дальнейших исследовании.

этих работ выработаны критерии, которые ялякоя основой для проведения дальнейих йследовании. Известно, что данный седиментационный бассейн в основном погружался в мезокайнозойское время. Вследствие этого исследователи не сомневаются в перспективности этих отложений в центральной части исследуемой территории и на больших глубинах, но точных расчетов пока нет. В целях решения данной проблемы нами были изучены коллекторские свойства пород рассматриваемых возрастов нефтегазоносных структур Ялама, Худат в различных геологических условиях и на разных глубинах. Для удобства анализа все фактй отражающие физические параметры различных типов пород, принимающих участие в геологическом строении б рассматриваемых физических свойств были применены различные петрофизические методы. В результате была установлена закономерносьь в изменении плотности пород, их карбонатности, пористости, проницаемости и скорости распространения в них ультразвуковых волн.

Одако на теки методы исследований ожидемых результатов дали ввиду нх силной дислоцированности и выхода на дневную поверхность. С учетом характеристик образцов пород рассматриваемых возрастов с разрабатываемых месторождений северо-восточного склона юго-восточного погружения Большого Кавказа. Основной целью работы является изучение петрофизических параметров и коллекторских свойств пород мелового палеоген-миоценового возраста в тектонически сложнопостроенных поднятиях Ялама, Худат и Сиязанской моноклинали юго-восточного погружения Большого Кавказа в связи с его нефтегазоносностью.

\footnotetext{
Vagif Sh. Gurbanov (Author ID in Scopus: 26028826000) - Doctor of Geological and Mineralogical Sciences, Professor, Head of the Department of Oil and Gas Field Prospecting and Exploration (mob. tel:: +994 502 140969 ; e-mail: vagifqurbanov@mail.ru).
Nariman R. Narimanov (Author ID in Scopus: 650680018) - PhD in Geological and Mineralogical Sciences, Associate Professor of the Department of Oil and Gas Field Prospecting and Exploration (mob. tel.: +994 503073 321, e-mail: latif.sultan@mail.ru).
Latif A. Sultanov - Researcher of the Department of Oil and Gas Field Prospecting and Exploration (mob. tel.: +994 503 279 701, e-mail: latif.sultan@mail.ru). The contact person for correspondence. e-mail: qizqayit abbasova@yahoo.com) -mail: ibrahimlimubarize@gmail.com).

Гурбанов Вагиф Шыхы оглы - доктор геолого-минералогических наук, профессор, заведующий кафедрой поиска и разведки нефтяных и газовых месторождений (моб. тел.: +994502 140969 , e-mail: vagifqurbanov@mail.ru).

Нариманов Нариман Рустам оглы - кандидат геолого-минералогических наук, доцент кафедры поиска и разведки нефтяных и газовых месторождений моб. тел.: +994 50307332 1, e-mail: latif sultan@mal.ru).

Султанов Латиф Агамирза оглы - научный сотрудник кафедры поиска и разведки нефтяных и газовых месторождений (моб. тел.: +994 503279701 , Аббасова Гызгайыт Гудрат гызы - ведущий инженер кафедры поиска и разведки нефтяных и газовых месторождений (моб. тел.: +994 555488712 , e-mail: qizqayit abbasova $a$ yahoo com) Ибрагимли Мубаризе Сахраб̆ гыз e-mail: ibrahimlimubarize $($ gmail.com).
} 


\section{Introduction}

The South Caspian megadepression (SCMD), for the most part located in the territory of Azerbaijan, is one of the richest petroleum basins of the world. Hence the development of oil and gas industry has been and continues to be a major influence on the economics of Azerbaijan and a number of other concerned states.

Due to the topical nature of study of the petroleum potential of deep-level deposits, an extensive geophysical and geological exploration was performed in Azerbaijan over the recent years. Based on the results of this work, the underlying criteria for further reserach were developed. Azerbaijan is known as the world's first commercial producer of oil. However, despite the success in oil production development, no substantive oil and gas accumulation has been discovered to date in the Mesozoic and Paleogene deposits in the territory of the Republic. Meanwhile, the paleographic, paleotechtonic and paleogeodynamic formation conditions of these deposits are favorable and the scope of geological and geophysical research is impressive. Therefore, the study of petrophysical and reservoir properties of the above specified ages of deposits is highly relevant in the current circumstances $[1-3]^{*}$.

In the Pre-Caspian-Gubinskii oil and gas bearing region (Fig. 1), the use of seismic methods for the study of deep-level formations structure provided more information on their reservoir properties.

The Pre-Caspian-Gubinskii oil and gas bearing region is situated in the north-east of Azerbaijan, occupying a large portion of the Caspian Sea coastal part. Tectonically the region relates to the northern slope of the south-east meganticlinorium immersion of the Greater Caucasus, belonging to the Gusar-Shabran synclinorium.

\section{Petroleum potential \\ and litho-petrophysical features of Siyazan monocline Meso-Cenozoic deposits}

The explored territory features oil and gas bearing Upper Cretaceous, Eocene, OligoceneMiocene (Maykop), Middle High Miocene and Pliocene deposits. Commercial quantities of oil and gas accumulate in Siyazan monocline fields. In Yalama, Khudat, Talabi, Shurabad, Begimdag, Tekchai and

\footnotetext{
* Apart from the sources cited in the references, Azerbaijan Institute of Geophysics library materials were used.
}

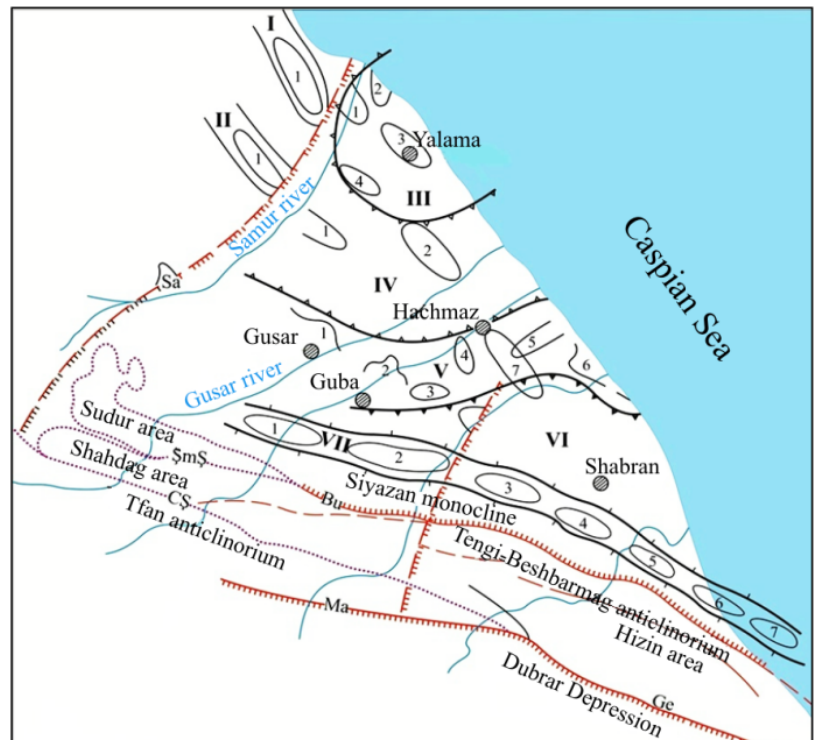

Figure. 1. Tectonic map of Pre-Caspian-Gubinskii oil and gas bearing region (after A. Suleimanov): I - East anticline area: 1 - Hoshmenzil. II - West anticline area: 1 - Ajinour. III - Yalama area (Paleozoic basement high): 1 - North Yalama; 2 - East Yalama; 3 - South Yalama; 4 - Shirvanovka. IV - Ziykhur Depression: 1 - Imamgulukent; 2 - Khudat. V - Gusar-Hachmaz area (Paleozoic basement high): 1 - Hazri-Gusar; 2 - Zizik; 3 - Guba; 4 - West Hachmaz; 5 - East Hachmaz; 6 - Agzybirchala; 7 - Hachmaz (these uplifts might be present in Pliocene deposits). VI - Divichin Depression. VII - Telebi-Gaynarcha anticline area: 1 - Nugadi; 2 - Telebi; 3 - West Gaynarcha; 4 - Gaynarcha; 5 - Gyzylburun; 6 - Gyzylburun-deniz; 7 - Zorat-deniz. Deep-level fractures: Sa - Samur, Ma - Malkomud, Ge - Germiyan. Regional displacements: ŞmŞ - North Shahdag, CŞ - South Shahdag, Bu - Budug

other areas oil and gas accumulations are also found, even if scarce. All in all, seven oil and gas fields out of forty five local uplifts have been discovered and commissioned in the south-east stretch of the Greater Caucasus.These are Siyazan monocline, ChangadarZarat, Siyazan-Nardaran, Saadan, Amirhanly, Zagly and Zeyva; Agzybirchala and Zarat-deniz were identified as exploration targets. The latter will be developed using the method of deep-level exploratory drilling [4-6].

The sedimentation structure part of interest has following lithological peculiarities.

The Upper Cretaceous deposits are mostly light grey limestones, marls, dark grey and grey sandstones, clays, in some of the areas - flysch. Specific resistivity of these types of rock reaches $100 \mathrm{Ohm} \cdot \mathrm{m}$.

Limestones are mainly fissured which is a sign of their secondary porosity. The proportion of limestones in the structure increases from the southeast to north-west (toward the Zagly-Zeyva area). 
Sandstones and limestones are mainly accumulated in the upper part of the structure, while in its middle part clays prevail. The penetrated thickness of Cretaceous deposits is $1645 \mathrm{~m}$.

Sumgait suite (Paleocene) can be traced all over the territory of Siyazan monocline. In ChandegerZarat area it transgressively overlaps the surface of the Cretaceous deposits. In Siyazan-Nardaran, Saadan, Amirhanly, Zagly-Zeyva areas, the overlapping lower part is presented by coeval deposits [7-9].

Koun suite (Eocene) is spread across the entire territory of Siyazan monocline, consisting of alternating sandy and calcareous clays, calcareous sandstones and fissured marls.

Lower Maykop deposits (Oligocene) are visible at the exposure as a thin stripe alongside the entire monocline. Lithologically they are represented by partings of quar, clays and conglomerates [10].

Upper Maykop (lower Miocene) mainly consists of clays and aleurolite with sand partings.

Chokrak-Spirialis horizon (Middle Miocene) consists of alternating thin interbeds of aleurolites, sandstones, clays and occasional gravelite and sand streaks.

Karagan horizon (Middle Miocene) in the upper part of the structure consists mainly of clays with occasional sandstone streaks with sandy and aleurolitic alternations.

Sarmatian stage (Upper Miocene) comes out to the daylight surface of Siyazan monocline as a wide stripe and mainly consists of sandstonestreaked aleurolites. In the lower part of the stage, clays with thickness up to 10 meters prevail.

Pliocene is represented by productive strata deposits (Lower Pliocene) and Akchagyl stage. To a large extent, these deposits comprise alternating clays and sands with conglomerate and tight sand interlayers.

Analysis of the rock samples established the density, grain size distribution, carbonate content, porosity, permeability, ultrasonic wave propagation velocity and magnetic susceptibility [11-14].

Tectonically the Siyazan monocline belongs to the complex structure of Tengi-Beshbarmag anticlinorium north-east wing, stretching from the north-east slope of the Greater Caucasus south-east basin. From the south-west, the monocline is limited by Hizin synclinorium, from the north-east - by Gusar-Shabran-Divichin discordant basin.
The geologically complex structure of Siyazan monocline can be categorized into several areas in terms of its oil and gas saturation, tectonic structure and geological properties. So, the uplands of the monocline feature Upper Cretaceous and PaleogeneMiocene deposits, while the lowland mainly consists of Pliocene deposits. Reservoir properties of all deposits are rather thoroughly studied. The received data served to produce a table of lithological, reservoir and other properties of the rock, establishing a certain trend in the development of their reservoir properties horizontally and the stratigraphic depth of various types of rock participating in the geological structure of the distinguished areas (Table 1).

Based on the Table 1, the main prospective targets of Siyazan monocline are Cretaceous and Paleocene-Miocene deposits. The shift in reservoir properties of the rock in deep and shallow wells shows that the porosity and permeability values in separate tectonic blocks, as well as other properties, have express distinguishing features. Reservoir properties tend to remain unchanged in the relatively deep parts of the structure. Meanwhile, in some of the areas, reservoir properties of the rock improve proportionally to the stratigraphic depth.

The deepest occurrence of Sumgait suite deposits uncovered by wells in Zeyva area is at $820-2415 \mathrm{~m}$. Density of clay rock at this depth is $1.90-1.95 \mathrm{~g} / \mathrm{cm}^{3}$, porosity is $20-25 \%$ (occasionally up to $30 \%$ ), ultrasonic waves propagation velocity is $1200-1300 \mathrm{~m} / \mathrm{s}$. Density of Maykop age aleurolites varies in the range between 2.56 and $2.65 \mathrm{~g} / \mathrm{cm}^{3}$, porosity is $15-30 \%$, and ultrasonic waves propagation velocity is 2000 $2500 \mathrm{~m} / \mathrm{s}$. Sandstones density is $2.07-2.55 \mathrm{~g} / \mathrm{cm}^{3}$, porosity is $8.2-22.5 \%$. Ultrasonic wave propagation velocity in sandstones, similarly to the other types of rock, depends on their lithographic composition and varies within $950-4000 \mathrm{~m} / \mathrm{s}$.

Paleogene age rocks detected in the monocline geological structure have following physical properties due to metamorphic changes: density $2.05-2.65 \mathrm{~g} / \mathrm{cm}^{3}$, porosity $-8.5-30 \%$, ultrasonic wave propagation velocity $-2100-4000 \mathrm{~m} / \mathrm{s}$ (see Table 1).

Table 1 presents Siyazan monocline data detailed by areas to facilitate their comparative study.

Thus, in order to study the Cretaceous and Paleocene-Miocene rock physical properties in Siyazan monocline depth- and area-wise, 
Table 1

Lithological composition and reservoir properties variability in Meso-Cenozoic (Cretaceous, Paleocene-Cretaceous) deposits across Siyazan monocline areas

\begin{tabular}{|c|c|c|c|c|c|c|c|c|}
\hline \multirow[b]{2}{*}{ Stratigraphy } & \multirow[b]{2}{*}{ Lithology } & \multirow{2}{*}{$\begin{array}{c}\text { Interval, } \\
\mathrm{m}\end{array}$} & \multirow{2}{*}{$\begin{array}{l}\text { Calcareous- } \\
\text { ness, } \%\end{array}$} & \multirow[b]{2}{*}{ Porosity, \% } & \multirow{2}{*}{$\begin{array}{l}\text { Permeability, } \\
\qquad 10^{-15} \mathrm{~m}^{2}\end{array}$} & \multicolumn{2}{|c|}{ Density $\sigma, \mathrm{g} / \mathrm{cm}^{3}$} & \multirow{2}{*}{$\begin{array}{c}\text { Wave } \\
\text { propagation } \\
\text { velocity } V, \mathrm{~m} / \mathrm{s}\end{array}$} \\
\hline & & & & & & dry & wet & \\
\hline \multicolumn{9}{|c|}{ Zeyva field } \\
\hline Maykop & $\begin{array}{c}\text { Sandy- } \\
\text { argillaceous } \\
\text { aleurolite }\end{array}$ & $\begin{array}{l}1190- \\
2355\end{array}$ & $\frac{2.1-33.5}{13.66(7)}$ & $\frac{2.5-20.4}{8.9(6)}$ & 0.003 & $\frac{2.50-2.54}{2.52(8)}$ & $\frac{2.53-2.60}{2.58(8)}$ & $\frac{1100-1800}{1500(8)}$ \\
\hline $\begin{array}{c}\text { Sumgait } \\
\text { (Paleocene) }\end{array}$ & $\begin{array}{c}\text { Sandy- } \\
\text { argillaceous } \\
\text { aleurolite }\end{array}$ & $820-821$ & 3.4 & 28.1 & 495.7 & 1.90 & 1.95 & 1300 \\
\hline Paleocene & $\begin{array}{c}\text { Sandy } \\
\text { aleurolite }\end{array}$ & $\begin{array}{c}1590- \\
1883\end{array}$ & $\frac{0.5-17.1}{5.94(7)}$ & $\frac{8.5-22.6}{15.0(7)}$ & $\frac{0.001-6.7}{0.96(7)}$ & $\frac{2.40-2.48}{2.42(7)}$ & $\frac{2.43-2.50}{2.45(7)}$ & $1700(1)$ \\
\hline Paleocene & $\begin{array}{c}\text { Sandy } \\
\text { aleurolite }\end{array}$ & $\begin{array}{c}2064- \\
2065 \\
\end{array}$ & 10.6 & 9.7 & 4.1 & 2.01 & 2.10 & $1100(1)$ \\
\hline $\begin{array}{c}\text { Sumgait } \\
\text { (Paleocene) }\end{array}$ & $\begin{array}{c}\text { Sandy- } \\
\text { argillaceous } \\
\text { aleurolite } \\
\end{array}$ & $\begin{array}{c}2412- \\
2415\end{array}$ & 2.5 & 19.5 & 0.001 & 2.04 & 2.18 & 1450 \\
\hline $\begin{array}{c}\text { Sumgait } \\
\text { (Paleocene) }\end{array}$ & $\begin{array}{c}\text { Sandy- } \\
\text { argillaceous } \\
\text { aleurolite }\end{array}$ & $\begin{array}{c}1632- \\
1952\end{array}$ & $\frac{0.8-66.0}{20.9(4)}$ & $\frac{4.4-8.4}{6.2(4)}$ & 0.001 & $\frac{1.80-1.87}{1.83(7)}$ & $\frac{1.83-1.90}{1.85(7)}$ & $0700-1200(2)$ \\
\hline Aalenian & $\begin{array}{c}\text { Sandy } \\
\text { aleurolite }\end{array}$ & $\begin{array}{c}1900- \\
1903 \\
\end{array}$ & $\frac{42.5-42.5}{42.5(2)}$ & $\frac{12.2-12.2}{12.2(2)}$ & 0.001 & $\frac{2.48-2.50}{2.49(2)}$ & $\frac{2.51-2.58}{2.55(2)}$ & $1300(1)$ \\
\hline \multicolumn{9}{|c|}{ Begimdag-Tekchai field } \\
\hline $\begin{array}{c}\text { Lower } \\
\text { Cretaceous } \\
\mathrm{K}_{1} \\
\end{array}$ & $\begin{array}{l}\text { Medium } \\
\text { grained } \\
\text { aleurolite }\end{array}$ & $\begin{array}{l}828- \\
2316\end{array}$ & $\frac{1.7-28.4}{16.4(19)}$ & $\frac{3.0-8.0}{6.9(6)}$ & $\frac{0.001-0.663}{0.18(5)}$ & $\frac{2.58-2.68}{2.60(15)}$ & $\frac{2.60-2.68}{2.64(15)}$ & $\frac{3100-4200}{3800(6)}$ \\
\hline $\begin{array}{c}\text { Valanginian } \\
\mathrm{K}_{1}^{2} \\
\end{array}$ & Sandy clays & $\begin{array}{c}2443- \\
3190\end{array}$ & $\frac{7.2-64.0}{29.9(7)}$ & $\frac{1.1-2.7}{2.3(4)}$ & $\approx 0.1$ & $\frac{2.31-2.40}{2.33(5)}$ & $\frac{2.36-2.43}{2.38(5)}$ & $\frac{1200-1800}{1600(3)}$ \\
\hline \multicolumn{9}{|c|}{ Tekchai field } \\
\hline $\begin{array}{c}\text { Aptian- } \\
\text { Barremian } \\
\mathrm{K}_{1}^{4,5} \\
\end{array}$ & $\begin{array}{c}\text { Sandy- } \\
\text { aleurolite clays }\end{array}$ & $\begin{array}{l}99.7- \\
511.2\end{array}$ & $\frac{10.0-77.0}{29.0(13)}$ & $\frac{2.2-2.26}{2.22(5)}$ & - & $\frac{2.20-2.52}{2.22(12)}$ & Av. 2.30 & $\frac{1220-4290}{1920(12)}$ \\
\hline \begin{tabular}{c|} 
Hauterivian \\
$\mathrm{K}_{1}^{3}$
\end{tabular} & $\begin{array}{l}\text { Sandy } \\
\text { aleurolite }\end{array}$ & $\begin{array}{c}1405- \\
1716\end{array}$ & $\frac{6.7-68.1}{32.8(45)}$ & $\frac{2.3-12.3}{7.5(45)}$ & $\frac{0.001-10.2}{0.89(34)}$ & $\frac{2.31-2.61}{2.43(20)}$ & Av. 2.52 & $\frac{1700-3500}{2050(20)}$ \\
\hline $\begin{array}{c}\text { Valanginian } \\
\mathrm{K}_{1}^{2}\end{array}$ & $\begin{array}{c}\text { Sandy } \\
\text { aleurolite }\end{array}$ & $\begin{array}{l}1757- \\
2349\end{array}$ & $\frac{0.8-63.1}{34.6(41)}$ & $\frac{1.0-14.6}{5.12(45)}$ & $\frac{0.001-0.46}{0.1(35)}$ & $\frac{2.31-2.54}{2.50(9)}$ & Av. 2.54 & $\frac{1700-3700}{2900(9)}$ \\
\hline \multicolumn{9}{|c|}{ Yashma field } \\
\hline $\begin{array}{c}\text { Meotian } \\
N_{1}^{2_{11}}\end{array}$ & $\begin{array}{c}\text { Sandy- } \\
\text { aleurolite clays }\end{array}$ & $163-193$ & - & $\frac{22.4-28.3}{24.4(3)}$ & $\frac{0.001-0.4}{0.01(8)}$ & $\frac{1.91-2.08}{2.06(4)}$ & $\frac{1.96-2.14}{2.07(4)}$ & $\frac{1000-2220}{2900(9)}$ \\
\hline $\begin{array}{c}\text { Sarmatian } \\
N_{1}^{2_{1}} \\
\end{array}$ & $\begin{array}{c}\text { Sandy- } \\
\text { aleurolite clays }\end{array}$ & $193-883$ & - & $\frac{11.7-40.8}{26.8(60)}$ & $\frac{0.7-78.3}{32.0(30)}$ & $\frac{1.86-2.54}{2.08(62)}$ & $\frac{1.90-2.64}{2.18(62)}$ & $\frac{600-5000}{1500(62)}$ \\
\hline \begin{tabular}{c|} 
Lower \\
Cretaceous \\
$\mathrm{K}$ \\
\end{tabular} & $\begin{array}{c}\text { Sandy- } \\
\text { aleurolite clays }\end{array}$ & $\begin{array}{l}900- \\
1697\end{array}$ & $\frac{63.2-79.4}{73.2(8)}$ & $\frac{15.3-27.0}{25.2(13)}$ & $\frac{0.04-29.4}{22.4(4)}$ & $\frac{1.90-2.12}{2.06(16)}$ & $\frac{2.10-2.20}{2.14(16)}$ & $\frac{710-2000}{1850(14)}$ \\
\hline
\end{tabular}

Note. In the fractions the numerators are extreme values, the denominators are average values of parameters, in brackets - the number of studied samples.

comparative study of all parameters listed in Table 1 was performed based on the samples collected from the monocline wells.

For Zeyva field, no direct correlation between decrease of rock permeability and increase of stratigraphic depth had been observed; nevertheless, there is a general trend towards stabilization of their values within 0.001 .
Permeability and porosity values withstand correlation. There is a low significance trend in decrease of porosity with increase of stratigraphic depth. Carbonate content and permeability are not related either, obviously due to the low values of carbonate content. Absence of correlation between porosity, permeability and carbonate content, as well as trends in porosity and permeability change 
depending on the stratigraphic depth could be caused by variability of clay fraction content in the examined types of rock.

For Begimdag-Tekchai area, it was noted that for two of the Low Cretaceous stratigraphic intervals, carbonate content of rock increases along with stratigraphic depth, while porosity and permeability decrease in the same direction.

As for Tekchai area, for three of the Low Cretaceous stratigraphic intervals, carbonate content of rock increases along with stratigraphic depth (adown); porosity generally increases in the same direction as well, while permeability drops down.

For Yashma area, the parameters in question were studied adown in Meotian, Sarmatian and Lower Cretaceous ages. The analysis results suggested that carbonate content was discovered only in the Lower Cretaceous deposits. Porosity slightly increases adown, while permeability generally increases in the same direction by a factor of hundreds.

As it is evident from the foregoing description of the examined parameters, no distinct regularity was established in terms of change in their values area-wise and depth-wise. However, according to
Table 2, seismic-wave velocity apparently increases in calcareous rocks (limestones) in Yalama, Siyazan and Atachai-Gilgilchai areas.

Besides, a direct correlation was established between density and ultrasonic waves propagation velocity that both increase in Cretaceous deposits in the northern (Yalama uplift) and southern (Tengialty-Beshbarmag anticlinorium) directions. Another finding was the significant variability of particle size and physical rock properties depthwise.

The performed analysis helped to ascertain the lithological diversity of the major depositional sequences related to paleographic and paleotectonic conditions of their genesis. Yet another regularity was established between the porosity factor and permeability factor variability [15].

Ultrasonic wave propagation analysis showed that despite a certain variation in the Upper Cretaceous rock density within Siyazan monocline, the ultrasonic wave propagation velocity increases adown. Concurrently, the velocity variability in limestones and calcareous clays is very similar, i.e. significantly higher than in non-calcareous rocks (see Table 2).

Table 2

Variability of density and ultrasonic wave propagation velocity in terrigenous-carbonate rock

\begin{tabular}{|c|c|c|c|c|c|}
\hline \multirow{2}{*}{ Area } & \multirow{2}{*}{ Lithology } & \multicolumn{2}{|c|}{ Density $\sigma, \mathrm{g} / \mathrm{cm}^{3}$} & \multicolumn{2}{c|}{ Ultrasonic wave propagation velocity $V, \mathrm{~m} / \mathrm{s}$} \\
\cline { 3 - 6 } & & Variability limits & Mean value & Variability limits & Mean value \\
\hline \multirow{2}{*}{ Yalama } & Clay (mudstone) & $2.40-2.48$ & 2.43 & $2600-2900$ & 2700 \\
\cline { 2 - 6 } & Limestone & $2.56-2.65$ & 2.59 & $4300-5600$ & 4600 \\
\hline \multirow{3}{*}{ Siyazan } & Clay & $2.20-2.44$ & 2.40 & $2200-2900$ & 2590 \\
& Limestone & $2.52-2.62$ & 2.54 & $3300-3900$ & 3700 \\
\cline { 2 - 6 } & Clay & $2.31-2.46$ & 2.44 & $2400-2900$ & 2800 \\
\hline Atachai-Gilgilchai & Limestone & $2.44-2.65$ & 2.60 & $3500-4700$ & 4500 \\
\hline
\end{tabular}

In tectonically complex structures of Siyazan monocline, no expected result was obtained by means of various petrophysical methods of examination applied in the study of Cretaceous deposits. Since vertically the physical parameters variability is irregular, it appears that the rocks were formed in metamorphic paleographic conditions at the sedimentation stage [16-18].

In order to establish the interconnection between the rock density variability and compressional seismic wave propagation velocity between the deep-level and overlying lithofacial complexes in Pre-Caspian-Gubinskii region, the data analysis was performed horizontally and vertically for Cretaceous calcareous clays. The results of the study are provided in Table 3. The data analysis based on Table 3 shows significant increase of density and compressional waves velocity values in Cretaceous deposits northward (Yalama uplift) and southward (Tengin-Beshbarmag anticlinorium) of Siyazan monocline [19].

Graphic analytic method was employed for examination of rock properties downward variation in some of the oil and gas bearing areas of PreCaspian-Gubinskii region. As a result, analytical expressions for downward variation of rock physical parameters in Pre-Caspian-Gubinskii region were determined. The data is provided in Table 3 and Figure 2. Table 3 reflects the downward variation of rock physical parameters 
Table 3

Analytical expressions for downward variation of rock physical parameters

\begin{tabular}{|c|c|c|c|}
\hline Age & Lithology & $\sigma=f(H)$ & $V=f(H)$ \\
\hline Aptian + & Calcareous & $2.85-0.42 e^{-0.45 H}$ & $4.62-3.4 e^{-0.45 H}$ \\
+ Hauterivian, & clay rock & $2.91-0.68 e^{-0.45 H}$ & \\
Lower & & $2.92-0.26 e^{-0.45 H}$ & $5.4-2.6 e^{-0.45 H}$ \\
Cretaceous & & & \\
\hline Valanginian, & Limestones & $2.85-0.40 e^{-0.45 H}$ & $4.8-2.9 e^{-0.45 H}$ \\
\cline { 2 - 4 } Lower & Sandy clay & $2.72-0.42 e^{-0.45 H}$ & $4.0-2.5 e^{-0.45 H}$ \\
Cretaceous & rock & $2.73-0.67 e^{-0.45 H}$ & \\
& & $2.72-0.51 e^{-0.45 H}$ & $3.7-2.2 e^{-0.45 H}$ \\
\hline
\end{tabular}

$\sigma$, dry, $\mathrm{g} / \mathrm{cm}^{3} \quad \sigma$, wet, $\mathrm{g} / \mathrm{cm}^{3} \quad V, \mathrm{~km} / \mathrm{s}$



$\mathrm{H}, \mathrm{km}$

Figure 2. Diagram of rock physical parameters downward variation in Pre-Caspian-Gubinsky region:

1 - Aptian and Hauterivian rocks;

2 - Valanginian limestones

in heterochronous structures of Pre-CaspianGubinskii region. Based on the analysis of the received data and generated curves, it is evident that despite negligible downward variability of Pre-Caspian-Gubinskii region Upper Cretaceous rock density, the compressional wave propagation velocity in these structures substantially increases in this direction. The regularity behind the downward variation of compressional wave propagation velocity in limestones and calcareous clay rock is virtually the same. It is notable that in the tectonically complex structures of Pre-CaspianGubinskii region, the application of graphic analytic method for examination of Cretaceous deposits did not provide the expected result. The vertical variability of physical parameters in this area is irregular and step-like, probably due to the variability of sedimentation paleographic conditions and further processes of their lithological and tectonic transformation.

The established dependencies can be applied for interpretation of geological and geophysical materials within the territory of research.

\section{Concerning lithological and petrophysical properties of Cretaceous, Paleogene-Miocene deposits in Yalama-Khudat areas}

Yalama and Khudat uplifts are developed in the south-east immersion of the Greater Caucasus. These structures are formed by Meso-Cenozoic deposits. Petroleum potential of these areas had been explored by means of seismic survey and prospective drilling. Oil and gas bearing Upper Cretaceous, Paleocene, Eocene, OligoceneMiocene (Maykop) and Middle High Miocene deposits were discovered. Out of these deposits, commercial grade oil and gas are produced in Siyazan monocline uplifts, Yalama, Khudat, Talabi, Shurabad, Begimdag-Tekchai and others with minor oil and gas accumulations.

Discussing the structural and tectonic nature of the south-east immersion of the Greater Caucasus, one must note that along with the local uplifts of general Caucasus trend, certain anti-Caucasus structures are also developed. The basic structures of Pre-Caspian-Gubinskii oil and gas bearing region of Yalama-Khudat and Agzybirchalin uplift are separated from the Gusar structure and TalabiGaynarcha anticlinorium area by a wide syncline (see Figure 1). In the two-part depression the thickness of deposits gradually increases from north-west to south-east from 1000 to $1500 \mathrm{~m}$. The depression expands in the south-eastern direction and stretches into the Caspian Sea. Thickness of Paleocene deposits in Yalama-Khudat uplifts varies within 100 and $370 \mathrm{~m}$. While Khudat area ends with a $200 \mathrm{~m}$ paleostructural hypsometric curve, Yalama area has no structural closure.

High potential of Upper Cretaceous, Paleocene, Eocene, Oligocene, Oligocene-Miocene deposits in the central part of the examined territory and in the deep-level strata of these areas in general is unmistakable; nevertheless, there is no quantitative answer to this question so far. Within the examined territory, all Mesozoic deposits have been uncovered by drilling (2600-3700 m) [20].

Petrophysical rock parameters for the considered ages of south-east immersion of the Greater Caucasus and their reservoir properties within the excavation fields and local uplifts under development have been identified in the course of our research.

Importantly, the density, particle size distribution, carbonate content, ultrasonic wave propagation velocity, magnetic susceptibility, porosity, permeability of rocks collected from the deep-level exploratory wells drilled in Yalama and Khudat uplifts, were studied using the latest scientific methods [21].

According to Table 4, carbonate content, reservoir properties, density and seismic wave propagation velocity in the areas under 
consideration were studied from Lower Pliocene (productive strata) to Jurassic deposits inclusive.

The productive strata deposits occur at a depth of 955-1235 $\mathrm{m}$ and are mostly represented by argillaceous sandstones with low carbonate content $(11.6 \%)$. At $20.2 \%$ porosity, the permeability is $1837 \cdot 10^{-15} \mathrm{~m}^{2}$, density is $2.1-2.5 \mathrm{~g} / \mathrm{cm}^{3}$. Average ultrasonic wave propagation speed in these deposits is $2800 \mathrm{~m} / \mathrm{s}$.

Sarmatian deposits were uncovered at a depth interval within 1236-1460 m. They consist of alternating sandstones, mudstones and clays with carbonate content over $15 \%$, porosity up to $20 \%$, permeability over $25 \cdot 10^{-15} \mathrm{~m}^{2}$ at rock density $2.15-2.57 \mathrm{~g} / \mathrm{cm}^{3}$. Ultrasonic wave propagation speed is $2000 \mathrm{~m} / \mathrm{s}$.

Seismic wave propagation velocity decrease in Sarmatian deposits at almost identical density with productive strata deposits may be caused by high clay content of the sequence.
Karagan stage deposits occur at a depth of 1462-1864 m and are composed of clays with carbonate content over $14 \%$, porosity over $20 \%$ at permeability $730.5 \cdot 10^{-15} \mathrm{~m}^{2}$ and density $2.11-$ $2.67 \mathrm{~g} / \mathrm{cm}^{3}$. Ultrasonic wave propagation velocity is $1900 \mathrm{~m} / \mathrm{s}$. In this case, the ultrasonic wave velocity decrease is probably caused by low cementation of sandstones.

In the examined area, Chokrak horizon is uncovered at a depth within 1870-2080 m and consists of clays with density $2.08-2.68 \mathrm{~g} / \mathrm{cm}^{3}$, carbonate content $38 \%$ at porosity over $21.7 \%$ and permeability $9.2 \cdot 10^{-15} \mathrm{~m}^{2}$. Ultrasonic wave propagation velocity is $1750 \mathrm{~m} / \mathrm{s}$. The data suggests that the most distinct regularity in the Chokrak horizon is inverse dependency between carbonate content of the sequence and ultrasonic wave propagation velocity. This is common for all the previous stratigraphic intervals, i.e. the increasing carbonate content contributes to the decrease of ultrasonic wave propagation velocity.

Table 4

Variability of lithological composition and reservoir properties of Meso-Cenozoic deposits in Yalama-Khudat areas

\begin{tabular}{|c|c|c|c|c|c|c|c|c|}
\hline \multirow{2}{*}{ Stratigraphy } & \multirow{2}{*}{$\begin{array}{c}\text { Interval, } \\
\mathrm{m}\end{array}$} & \multirow{2}{*}{ Lithology } & \multirow{2}{*}{$\begin{array}{l}\text { Carbonate } \\
\text { content, } \%\end{array}$} & \multirow{2}{*}{ Porosity, \% } & \multirow{2}{*}{$\begin{array}{c}\text { Permeability, } \\
10^{-15} \mathrm{~m}^{2}\end{array}$} & \multicolumn{2}{|c|}{ Density $\sigma, \mathrm{g} / \mathrm{cm}^{3}$} & \multirow{2}{*}{$\begin{array}{c}\text { Wave propagation } \\
\text { velocity } V, \mathrm{~m} / \mathrm{s}\end{array}$} \\
\hline & & & & & & wet & dry & \\
\hline \multirow{2}{*}{$\begin{array}{l}\text { Productive } \\
\text { strata }\end{array}$} & $955-$ & Argillaceous & 7.0-20.0 & $\underline{7.05-30.0}$ & $\underline{0.32-177.3}$ & $1.94-2.63$ & $\underline{1.90-2.36}$ & $\underline{2500-3000}$ \\
\hline & 1235 & sandstone & $11.6(7)$ & $20.23(8)$ & $18.36(7)$ & $2.54(8)$ & $2.15(8)$ & $2800(8)$ \\
\hline \multirow{2}{*}{ Sarmatian } & $1236-$ & Sandstone, & $9.0-20.0$ & $6.15-30.1$ & $\underline{0.69-98.8}$ & $2.48-2.67$ & $\underline{1.78-2.29}$ & $\underline{1800-2200}$ \\
\hline & 1460 & mudstone, clay & $15.25(13)$ & $19.89(9)$ & 25.36 & 2.57 & 2.15 & 2000 \\
\hline \multirow[b]{2}{*}{ Karagan } & $1462-$ & & $\underline{4.0-27.0}$ & 3.9-29.0 & $4.2-4429$ & $2.10-2.88$ & $1.73-2.36$ & $\underline{1550-2000}$ \\
\hline & 1864 & Sandstone & 14 & 20.5 & 730.5 & 2.67 & 2.11 & 1900 \\
\hline \multirow{2}{*}{ Chokrak } & 1870 & & 5.9-45.2 & $\underline{10.0-33.0}$ & & $\underline{1.88-2.88}$ & $1.88-2.27$ & $\underline{1500-1850}$ \\
\hline & 2080 & Clay & 38.2 & 21.7 & 9.2 & 2.68 & 2.08 & 1750 \\
\hline \multirow{2}{*}{ Maykop } & $2080-$ & Sandstone clay & $\underline{8.4-98.5}$ & $\underline{1.0-26.0}$ & $\operatorname{Imn}$ & $2.56-2.77$ & $1.98-2.54$ & $2000-2800$ \\
\hline & 2585 & Sandstone, clay & 76.3 & 15.7 & Imp. & 2.72 & 2.29 & 2500 \\
\hline Maastrichtian & $\begin{array}{l}2596- \\
2598\end{array}$ & $\begin{array}{l}\text { Argillaceous } \\
\text { limestone }\end{array}$ & 32.8 & 5.0 & Imp. & 2.72 & 2.63 & 4700 \\
\hline \multirow{2}{*}{ Coniacian } & $2610-$ & Argillaceous & $\underline{49.2-78.0}$ & $\underline{3.2-6.8}$ & $\approx 001$ & $2.59-2.73$ & $2.57-2.67$ & 3800-5300 \\
\hline & 2633 & limestone & 666 & 5.22 & $\approx 0.01$ & 2.65 & 2.63 & 4700 \\
\hline \multirow[b]{2}{*}{ Turonian } & $2633-$ & Marl, & $62.8-96.0$ & $0.45-5.9$ & $0.014-8.4$ & $2.57-2.76$ & $2.50-2.68$ & $3950-5000$ \\
\hline & 2735 & $\begin{array}{l}\text { argillaceous } \\
\text { limestone }\end{array}$ & 84.36 & 4.16 & 1.45 & 2.67 & 2.60 & 4350 \\
\hline Albian & $\begin{array}{c}3061- \\
3074\end{array}$ & Sandstone & $\frac{17.0-32}{22.0}$ & $\frac{5.23-8.84}{7.15}$ & Imp. & 2.75 & 2.62 & 4500 \\
\hline Aptian & $\begin{array}{c}3074- \\
3229\end{array}$ & $\begin{array}{l}\text { Argillaceous } \\
\text { limestone, } \\
\text { mudstone }\end{array}$ & $\frac{17.0-26.0}{23.7}$ & $\frac{2.59-20.6}{14.6}$ & Imp. & 2.63 & 2.48 & 3850 \\
\hline Barremian & $\begin{array}{c}3605- \\
3696\end{array}$ & Sandstone & $\frac{3.4-4.3}{3.85}$ & $\frac{10.2-11.7}{10.95}$ & $\frac{0.1-0.8}{0.45}$ & $\frac{2.58-2.71}{2.62}$ & $\frac{2.48-2.59}{2.50}$ & 3000 \\
\hline Jurassic & $\begin{array}{c}3441- \\
3608\end{array}$ & $\begin{array}{l}\text { Aleurolite, } \\
\text { sandstone }\end{array}$ & 55.9 & 11.6 & Imp. & $\frac{2.55-2.73}{2.62}$ & $\frac{2.53-2.54}{2.53}$ & $\frac{3400-3510}{3450}$ \\
\hline
\end{tabular}

$\mathrm{N}$ o t e. In the fractions the numerators are extreme values, the denominators are average values; Imp. - impervious; in brackets is the number of studied samples. 
Maykop series in the studied region is uncovered within the depth interval of 2080-2585 m. Lithologically it is composed of alternating clays and sandstones with carbonate content values reaching above $76.3 \%$, at porosity $15.7 \%$ and complete absence of permeability with relatively high density $\left(2.29-2.72 \mathrm{~g} / \mathrm{cm}^{3}\right)$ and high ultrasonic waves velocity $(2500 \mathrm{~m} / \mathrm{s})$.

The correlation between Chokrak clays and Maykop argilio-arenaceous alternations seismic wave velocities, with the latter's carbonate content twice higher than that of the former, suggests the existence of a meaningful dependence of the ultrasonic wave propagation velocity primarily on the lithological composition and density of the rocks. In Cenozoic sequence, this dependency is rather clearly manifest especially as the carbonate content raises.

In the areas under consideration, the Mesozoic sequence starts from Maastrichtian stage discovered in the 2596-2598 m depth interval and expressed in argillaceous limestone with density $2.63-2.72 \mathrm{~g} / \mathrm{cm}^{3}$, carbonate content over $32.8 \%$ at porosity $5.0 \%$ and with no permeability. Ultrasonic wave propagation velocity drastically increases up to $4700 \mathrm{~m} / \mathrm{s}$. Obviously, limestone argillization and intense packing resulted in disappearance of permeability and ultrasonic wave propagation velocity increase.

Coniacian stage occurs at a depth of 2610 $2633 \mathrm{~m}$ and consists of argillaceous limestones with carbonate content over $66 \%$ at porosity over $5 \%$ and permeability up to $0.01 \cdot 10^{-15} \mathrm{~m}^{2}$. Rock density is over $2.6 \mathrm{~g} / \mathrm{cm}^{3}$, ultrasonic wave propagation velocity is $4700 \mathrm{~m} / \mathrm{s}$, same as in the previous case of this type of rock.

Turonian deposits uncovered in the depth of 2633-2735 m consists of malmrock and argillaceous limestones with carbonate content over $84 \%$, porosity over $4 \%$ and permeability $1.45 \cdot 10^{-15} \mathrm{~m}^{2}$. Rock density is $2.60-2.67 \mathrm{~g} / \mathrm{cm}^{3}$, while the ultrasonic wave propagation velocity is somewhat lower than that of the Coniacian, amounting to $4350 \mathrm{~m} / \mathrm{s}$. It can be assumed that the decrease in the ultrasonic wave propagation velocity is related to porosity growth by a factor of several times in Turonian deposits.

Albian stage within the area of research is uncovered at the depth of 3061-3074 $\mathrm{m}$ and is represented by sandstones with carbonate content $22 \%$, porosity over $7 \%$ and absence of permeability. Density of Albian sandstones is $2.62-2.75 \mathrm{~g} / \mathrm{cm}^{3}$.
Compressional wave velocity in these deposits increases up to $4500 \mathrm{~m} / \mathrm{s}$. Apparently the ultrasonic wave propagation velocity increase in Albian sandstones is caused by their relatively high density and low porosity.

Aptian deposits are uncovered in the interval within 3074-3229 $\mathrm{m}$ and are composed of argillaceous limestones and mudstone with carbonate content over $23 \%$ and no permeability. The rock density is $2.48-2.63 \mathrm{~g} / \mathrm{cm}^{3}$.

Ultrasonic wave propagation velocity in these rocks goes down to $3850 \mathrm{~m} / \mathrm{s}$, which is apparently related to the decreasing density and increasing porosity.

Barremian stage expressed in sandstones is uncovered in the depth interval within 3605-3696 m. Rock carbonate content is around $4 \%$ at porosity up to $11 \%$, permeability $0.45 \cdot 10^{-15} \mathrm{~m}^{2}$ and density $2.50-2.62 \mathrm{~g} / \mathrm{cm}^{3}$. Ultrasonic wave propagation velocity is $3000 \mathrm{~m} / \mathrm{s}$. Its considerable decrease versus the velocity in Aptian deposits at nearly level density and negligible difference in other parameters may be related to the drop in the Barremian sandstones carbonate content.

Jurassic deposits of the area of interest were uncovered at a depth of 3441-3608 m. Lithologically they mostly consist of aleurolites and sandstones with carbonate content over $56 \%$, which is way higher than the same parameter of the Barremian sandstones.

Porosity of Jurassic deposits is by $0.65 \%$ higher than that of the Barremian sandstones; they are impervious at density $2.53-2.62 \mathrm{~g} / \mathrm{cm}^{3}$, i.e. level with the Barremian. However, the ultrasonic wave propagation velocity in Jurassic deposits is $450 \mathrm{~m} / \mathrm{s}$ higher than in the Barremian sequence.

Drawing on the foregoing data, one might conclude that in Cenozoic deposits the ultrasonic wave propagation velocity inversely correlates with rock porosity. This is less evident in Mesozoic deposits. A relatively low direct correlation exists between the values of carbonate content and ultrasonic wave propagation velocity. Overall, the ultrasonic wave propagation velocity gradually increases along with stratigraphic depth, despite slight fluctuations. There is a stronger direct correlation between the rock density and ultrasonic wave propagation velocity.

Based on Table 4, a petrophysical model reflecting the reservoir rock properties in Yalama and Khudat areas was designed (Table 5). 
Table 5

Rock porosity variation depending on their lithological and petrophysical properties

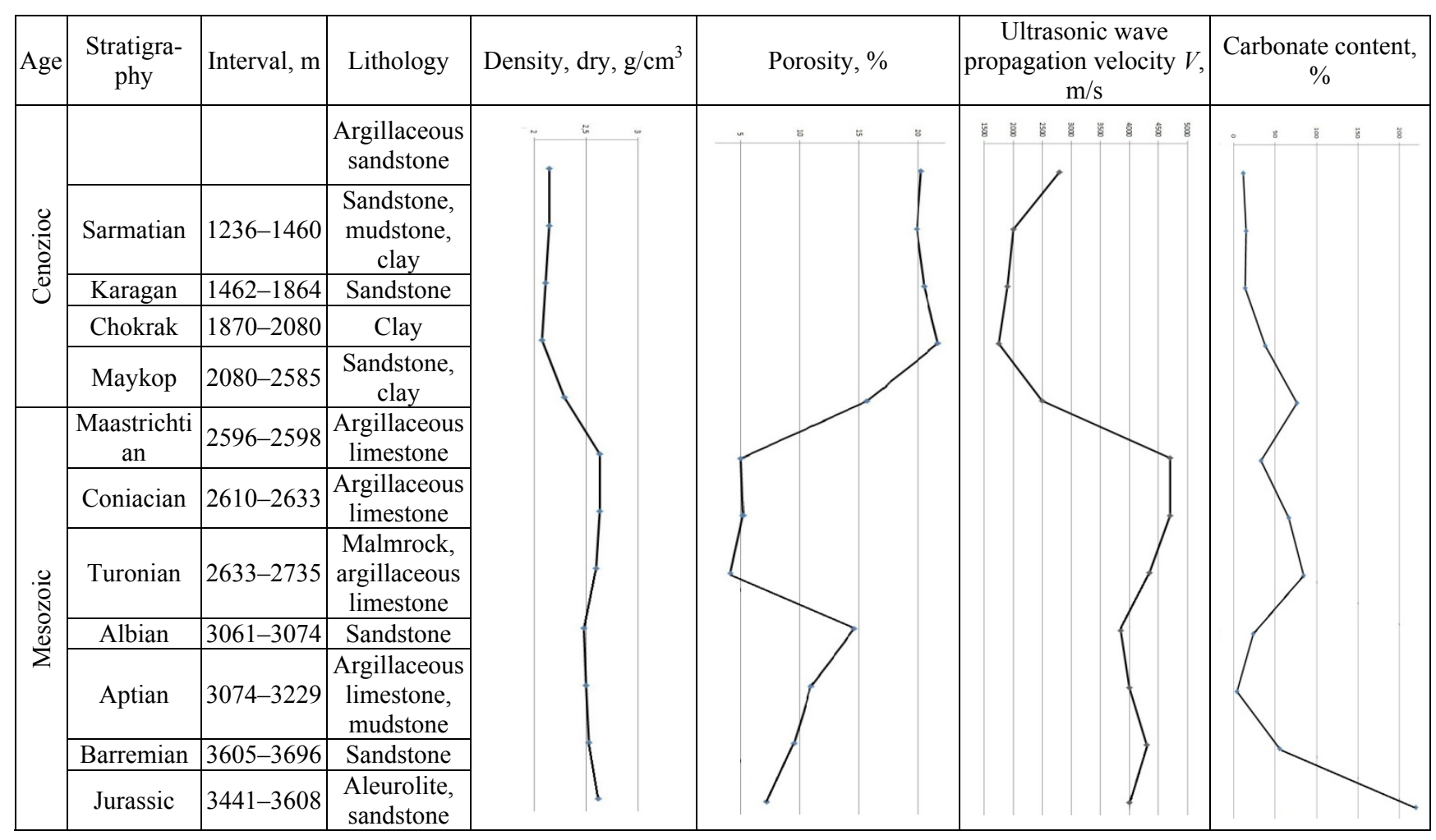

Table 5 makes clear that reservoir properties of rocks exhibit certain downward changes, i.e. there is an inverse relation between increasing density and ultrasonic waves propagation velocity, on the one hand, and decreasing rock porosity, on the other hand.

Probably this happens due to the increasing geostatic pressure. The comparison of the built curves suggests that in the Sarmatian-Chokrak sedimentation sequence stratigraphic interval its relatively low rock density, ultrasonic wave propagation velocity and carbonate content go hand in hand with higher porosity $[22,23]$.

In Maykop-Maastrichtian interval of the sequence consisting of sand-clay lithologies and limestones, the bottom surface of Maastrichtian bed exhibits the increase of density and ultrasonic wave propagation velocity along with minor decrease in carbonate content and significant decrease in porosity.

The third interval of the sequence is contained between the Maastrichtian bottom surface and the Turonian and primarily consists of argillaceous limestones. Its characteristic feature is rock density increase and the highest ultrasonic wave propagation velocity throughout the entire sedimentation sequence at low carbonate content and minimal porosity. Based on the comparison of the curves, it is evident that low porosity is quite concordant with respective variations of other parameters.

In the Albian interval represented by sandstones, a significant increase in the rock porosity is accompanied by fairly stable density and minor increase of ultrasonic wave propagation velocity.

Finally, in Apt-Barrem-Jurassic interval of the sedimentation sequence, rock porosity decreases by a factor of two, while density remains nearly flat, ultrasonic waves propagation velocity fluctuates slightly, and carbonate content exhibits relatively rapid growth in the Jurassic deposits of the sequence.

This can be explained by deterioration of their reservoir properties with increase of stratigraphic depth. Speaking about the downward variation of individual parameters, it is notable that despite e certain shift in the rock density, ultrasonic wave propagation velocity in these deposits grows swiftly up starting from Coniacian age. Meanwhile, in the limestones and calcareous clays the compressional wave velocity downward variability trend is virtually the same. 
In order to confirm the results of the research within the studied areas, we employed the graphic analysis method developed by M. Ozerskaia. In the output, we received the analytical expression for variation of physical rock properties depending on the stratigraphic depth [24-26] and built their graphic model.

Drawing on the aforementioned, there is a direct, i.e. immediate, correlation between porosity and the considered petrophysical rock properties throughout the entire examined stratigraphic interval of the sedimentation sequence in the area of study.

\section{Summary}

The conducted research resulted in the following findings:

1. Wide-range horizontal variability of reservoir rock properties is mainly related to the lithogenesis conditions, lithological diversity of sedimentation structures, depth of the rocks occurrence, and individual developmental properties of local uplifts.

2 . The results of petrophysical research helped to detect the ultrasonic wave propagation velocity increase along with increase of the rock density and downward lessening of their reservoir properties.

3. Seismic wave propagation velocity increases in limestones and, more rarely, in the deposits with high levels of carbonate content, as well as, slightly variably, with increase of the stratigraphic depth.

4. In order to estimate the petroleum potential of the deep-level strata in the examined territory, it is advisable, along with exploratory geophysical methods, to draw on the results of reservoir rock properties variability analysis by petrophysical methods, as well as on the trends of depth-wise seismic wave propagation velocity variation.

\section{References}

1. Iusifzade Kh.B. Primenenie sovremennykh tekhnologii $\mathrm{v}$ oblasti razvedki i dobychi neftegazovykh mestorozhdenii $\mathrm{v}$ Azerbaidzhane [Application of modern technologies in the field of exploration and production of oil and gas fields in Azerbaijan]. Zhurnal ANKh, 2013, no.7-8, pp.3-13.

2. Kerimov K.M., Rakhmanov R.R., Kheirov M.B. Neftegazonosnost' Iuzhno-Kaspiiskoi megavpadiny [Petroleum potential of the South Caspian megadepression]. Baku, 2001, $317 \mathrm{p}$.

3. Khain V.E. Tektonika neftegazonosnykh oblastei iugo-vostochnogo pogruzheniia Bol'shogo Kavkaza [Tectonics of the oil and gas bearing areas of southeast dipping of the Greater Caucasus]. Moscow: Gostoptekhizdat, 1958, $224 \mathrm{p}$.

4. Vassoevich N.B., Librovich V.L., Logvinenko N.V., Marchenko V.I. (Ed.) Spravochnik po litologii [Handbook on lithology]. Moscow: Nedra, 1983, 509 p.

5. Spravochnik po geologii nefti i gaza [Handbook on Petroleum Geology]. Moscow: Nedra, 1988, 480 p.

6. Ali-zade A.A., Akhmedov G.A., Akhmedov A.M., Aliev A.K., Zeinalov M.M. Geologiia neftianykh i gazovykh mestorozhdenii Azerbaidzhana [Geology of of oil and gas fields in Azerbaijan]. Moscow: Nedra, 1966, 390 p.

7. Babazade B.Kh., Putkaradze L.A. O poiskakh zalezhei gaza i nefti $\mathrm{v}$ pribrezhnoi morskoi zone Apsheronskogo poluostra i Bakinskogo arkhipelaga [On the search for oil and gas deposits in the coastal marine area of the Absheron peninsula and Baku archipelago]. Geologiia nefti i gaza, 1961, no.10, pp.7-11.

8. Sokolov B.A. Evoliutsiia i neftegazonosnost' osadochnykh basseinov [Evolution and petroleum potential of sedimentary basins]. Moscow: Nauka, 1980, 243 p.
9. Uspenskaia N.Iu., Tauson N.N. Neftegazonosnye provintsii i oblasti zarubezhnykh stran [Oil and gas bearing provinces and areas of foreign countries]. Moscow: Nedra, 1972, $283 \mathrm{p}$.

10. Ali-Zade A.A., Salaev S.G., Aliev A.I. Nauchnaia otsenka perspektiv neftegazonosnosti Azerbaidzhana i Iuzhnogo Kaspiia i napravlenie poiskovo-razvedochnykh rabot [Scientific evaluation of oil and gas potential of Azerbaijan and the South Caspian and direction of exploration]. Baku: Elm, 1985, 227 p.

11. Dortman N.B. (Ed.) Fizicheskie svoistva gornykh porod i poleznykh iskopaemykh [Physical properties of rocks and mineral resources]. Moscow: Nedra, 1976, $527 \mathrm{p}$.

12. Argenheisen G. (Ed.) Landolt-Bornstein tables. Physical properties of rocks. N.Y., 1983, vol. V, 373 p.

13. Theoretical and experimental investigations of physical properties of rocks and minerals under extreme p,T-conditions. Berlin: Academie Verlag, 1979, 232 p.

14. Afandiyeva M.A., Guliyev I.S. Maicop group-shale hydrocarbon complex in Azerbaijan. 75th EAGE Conference \& Exhibition incorporating SPE EUROPEC. London, 2013, pp.06-13. DOI: 10.3997/2214-4609.20130979.

15. Sostavlenie kataloga kollektorskikh svoistv mezokainozoiskikh otlozhenii mestorozhdenii nefti-gaza i perspektivnykh struktur Azerbaidzhana: otchet Nauchnoissledovatel'skogo instituta geofiziki № 105-2009 [Making catalog of reservoir properties of Meso-Cenozoic deposits of oil and gas prospective structures of Azerbaijan: report of the Research Institute of Geophysics number 105-2009]. Baku, 2010, 250 p.

16. Babaev M.S., Sultanov L.A., Ganbarova Sh.A., Alieva T.A. O rezul'tatakh petrofizicheskikh issledovanii otlozhenii produktivnoi tolshchi neftegazonosnykh 
ploshchadei Bakinskogo arkhipelaga [On the results of petrophysical studies of deposits in oil and gas bearing productive strata of Baku archipelago areas]. Izvestiia vysshikh tekhnicheskikh uchebnykh zavedenii Azerbaidzhana, 2014, no.2, pp.7-12.

17. Gurbanov V.Sh., Sultanov L.A., Abbasova G.G. Litologo-petrograficheskie i kollektorskie svoistva mezokainozoiskikh otlozhenii Prikaspiisko-Gubinskogo neftegazonosnogo raiona [Lithologic-petrographic and reservoir properties of Meso-Cenozoic deposits of the PreCaspian-Guba oil and gas bearing district]. Geofizicheskie novosti Azerbaidzhana, 2014, no.3-4, pp.10-13.

18. Sultanov L.A., Nadzhaf-Kuieva V.M., Abbasova G.G. O zakonomernosti raspredeleniia skorosti prodol'nykh voln i plotnosti osadochnykh porod PrikaspiiskoKubinskoi oblasti i mezhdurech'ia Kury i Gabyrry [On the distribution patterns of the longitudinal waves velocity and the density of sediments in the Caspian-Cuban region and between the rivers Kura and Gabyrry]. Tezisy dokladov XX Gubkinskikh chtenii, Moscow, 28-29 noiabria 2013. Moscow, 2013.

19. Gurbanov V.Sh., Babaev M.S., Sultanov L.A., Rustamova R.E. Kratkaia geologo-geofizicheskaia kharakteristika razreza zemnoi kory raiona Saatlinskoi sverkhglubokoi skvazhiny SG-1 [Brief geological and geophysical characteristics of the Earth's crust cut in Saatli district of the ultradeep well SG-1]. Azerbaidzhan geologu, 2012, no.16, pp.31-37.

20. Physical properties of the mineral system of the Earth's interior: international monograph Project 3 CAPG. Praha, 1985, 564 p.

21. Lebedev T.S. Model studies of physical properties of mineral matter in high pressure - temperature experiments. Phys. Earth and Planet. Inter., 1980, vol.25, pp.292-303. DOI: 10.1016/0031-9201(80)90126-0.

22. Rakhmanov R.R. Zakonomernosti formirovaniia $i$ razmeshcheniia zon neftegazonakopleniia $\mathrm{v}$ mezozoiskikh otlozheniiakh Azerbaidzhana [Oil and gas accumulation zones' formation and distribution patterns in the Mesozoic deposits of Azerbaijan]. Baku: Elm, 1985, 108 p.

23. Kozhevnikov D.A. Petrofizicheskaia invariantnost' granuliarnykh kollektorov [Petrophysical invariance of granular reservoir]. Geofizika, 2001, no.4, pp.31-37.

24. Rachinskii M.Z., Chilingar Dzh. Rezul'taty geologo-razvedochnykh rabot 1990-2005 gg., geologicheskie aspekty perspektiv i kolichestvennaia otsenka [Results of geological exploration in 1990-2005, geological aspects of prospects and quantitative evaluation]. Zhurnal ANKh, 2007, no.1, pp.7-15.

25. Mekhtiev U.Sh., Kheirov M.B. Litologopetrograficheskie osobennosti i kollektorskie svoistva porod kalinskoi i podkirmakinskoi svit Apsheronskoi neftegazonosnoi oblasti Azerbaidzhana [Lithologic and petrographic characteristics and reservoir properties of rocks in Podkirmak and Kali suites of Absheron oil and gas area of Azerbaijan]. Baku, 2007, part 1, p. 238.

26. Rakhmanov R.R., Sultanov L.A., NadzhafKulieva V.M., Ganbarova Sh.A. Otsenka perspektiv neftegazonosnosti PT nizhnego pliotsena melkovodnoi zony Apsheronskogo poluostrova i Bakinskogo arkhipelaga po kompleksnym dannym geologo-geofizicheskikh issledovanii [Estimation of oil and gas potential prospects of PT Lower Pliocene shallow areas of Absheron peninsula and Baku archipelago on integrated data of geological and geophysical studies]. Materialy mezhdunarodnogo seminara, Ukhta, 8-9 fevralia 2013. Ukhta, 2013.

\section{Список литературы}

1. Юсифзаде Х.Б. Применение современных технологий в области разведки и добычи нефтегазовых месторождений в Азербайджане // Журнал АНХ. 2013. - № 7-8. - C. 3-13.

2. Керимов К.М., Рахманов Р.Р., Хеиров М.Б. Нефтегазоносность Южно-Каспийской мегавпадины. Баку, 2001. - 317 с.

3. Хаин В.Е. Тектоника нефтегазоносных областей юго-восточного погружения Большого Кавказа. - М.: Гостоптехиздат, 1958. - $224 \mathrm{c.}$

4. Справочник по литологии / под ред. Н.Б. Вассоевича, В.Л. Либровича, Н.В. Логвиненко, В.И. Марченко. - М.: Недра, 1983. - 509 с

5. Справочник по геологии нефти и газа. - М.: Недра, 1988. - 480 с.

6. Геология нефтяных и газовых месторождений Азербайджана / А.А. Али-заде, Г.А. Ахмедов, А.М. Ахмедов, А.К. Алиев, М.М. Зейналов. - М.: Недра, 1966. - 390 с.

7. Бабазаде Б.Х., Путкарадзе Л.А. О поисках залежей газа и нефти в прибрежной морской зоне Апшеронского полуострова и Бакинского архипелага // Геология нефти и газа. - 1961. - № 10. - С. 7-11.
8. Соколов Б.А. Эволюция и нефтегазоносность осадочных бассейнов. - М.: Наука, 1980. - 243 с.

9. Успенская Н.Ю., Таусон Н.Н. Нефтегазоносные провинции и области зарубежных стран. - М.: Недра, 1972. -283 c.

10. Али-Заде А.А., Салаев С.Г., Алиев А.И. Научная оценка перспектив нефтегазоносности Азербайджана и Южного Каспия и направление поисково-разведочных работ. - Баку: Элм, 1985. - 227 с.

11. Физические свойства горных пород и полезных ископаемых / под ред. Н.Б. Дортман. - М.: Недра, 1976. $527 \mathrm{c}$.

12. Landolt-Bornstein tables. Physical properties of rocks / ed. G. Argenheisen. - N.Y., 1983. - Vol. V. $373 \mathrm{p}$.

13. Theoretical and experimental investigations of physical properties of rocks and minerals under extreme p,T-conditions. - Berlin: Academie Verlag, 1979. $232 \mathrm{p}$.

14. Afandiyeva M.A., Guliyev I.S. Maicop group-shale hydrocarbon complex in Azerbaijan // 75th EAGE Conference \& Exhibition incorporating SPE EUROPEC. - London, 2013. - P. 6-13. DOI: 10.3997/2214-4609.20130979. 
15. Составление каталога коллекторских свойств мезокайнозойских отложений месторождений нефтигаза и перспективных структур Азербайджана: отчет Научно-исследовательского института геофизики № 105-2009 / Фонды Управления геофизики и геологии. - Баку, 2010. - 250 с.

16. О результатах петрофизических исследований отложений продуктивной толщи нефтегазоносных площадей Бакинского архипелага / М.С. Бабаев, Л.А. Султанов, Ш.А. Ганбарова, Т.А. Алиева // Известия высших технических учебных заведений Азербайджана. - 2014. - № 2. - С. 7-12.

17. Гурбанов В.Ш., Султанов Л.А., Аббасова Г.Г. Литолого-петрографические и коллекторские свойства мезокайнозойских отложений Прикаспийско-Губинского нефтегазоносного района // Геофизические новости Азербайджана. - 2014. - № 3-4. C. $10-13$.

18. Султанов Л.А., Наджаф-Куиева В.М., Аббасова Г.Г. О закономерности распределения скорости продольных волн и плотности осадочных пород ПрикаспийскоГубинской области и междуречья Куры и Габырры // Тезисы докладов XX Губкинских чтений, Москва, 28-29 ноября 2013. - М., 2013.

19. Краткая геолого-геофизическая характеристика разреза земной коры района Саатлинской сверхглубокой скважины СГ-1 / В.Ш. Гурбанов, М.С. Бабаев, Л.А. Султанов, Р.Э. Рустамова // Азербайджан геологу. 2012. - № 16. - С. 31-37.
20. Physical properties of the mineral system of the Earth's interior: international monograph Project 3 CAPG. - Praha, 1985. - 564 p.

21. Lebedev T.S. Model studies of physical properties of mineral matter in high pressure - temperature experiments // Phys. Earth and Planet. Inter. - 1980. Vol. 25. - P. 292-303. DOI:10.1016/0031-9201(80)90126-0.

22. Рахманов Р.Р. Закономерности формирования и размещения зон нефтегазонакопления в мезозойских отложениях Азербайджана. - Баку: Элм, 1985. - 108 с.

23. Кожевников Д.А. Петрофизическая инвариантность гранулярных коллекторов // Геофизика. - 2001. № 4. - С. 31-37.

24. Рачинский М.3., Чилингар Дж. Результаты геолого-разведочных работ 1990-2005 гг., геологические аспекты перспектив и количественная оценка // Журнал АНХ. - 2007. - № 1. - С. 7-15.

25. Мехтиев У.Ш., Хеиров М.Б. Литолого-петрографические особенности и коллекторские свойства пород калинской и подкирмакинской свит Апшеронской нефтегазоносной области Азербайджана. Баку, 2007. - Ч. 1. - 238 с.

26. Оценка перспектив нефтегазоностности продуктивных толщ нижнего плиоцена мелководной зоны Апшеронского полуострова и Бакинского архипелага по комплексным данным геолого-геофизических исследований / Р.Р. Рахманов, Л.А. Султанов, В.М. НаджафКулиева, Ш.А. Ганбарова // Материалы международного семинара, Ухта, 8-9 февраля 2013. - Ухта, 2013.

Please cite this article in English as:

Gurbanov V.Sh., Narimanov N.R., Sultanov L.A., Abbasova G.G., Ibragimli M.S. The lithological-petrography characteristics of Chalk, Paleogen-Miocene deposits of Yalama-Khudat areas and Siyazan monocline anticline in connection with their oil and gas content (south-east immersions of megaanticlinoric of Greater Caucasus). Bulletin of PNRPU. Geology. Oil \& Gas Engineering \& Mining, 2016, vol.15, no.20, pp.204-215. DOI: 10.15593/2224-9923/2016.20.1

Просьба ссылаться на эту статью в русскоязычных источниках следующим образом:

Литолого-петрофизические характеристики меловых, палеоген-миоценовых отложений площадей Ялама, Худат и Сиязанской моноклинали в связи с их нефтегазоносностью (юго-восточное погружение мегантиклинория Большого Кавказа) / В.Ш. Гурбанов, Н.Р. Нариманов, Л.А. Султанов, Г.Г. Аббасова, М.С. Ибрагимли // Вестник Пермского национального исследовательского политехнического университета. Геология. Нефтегазовое и горное дело. - 2016. - Т.15, №20. - С. 204-215. DOI: $10.15593 / 2224-9923 / 2016.20 .1$ 